\title{
STUDY GROUP ON INTERNATIONAL LABOR AND WORKING CLASS HISTORY
}

The Study Group sponsored a panel discussion and business meeting on Dec. 28, 1978 at the recent AHA meeting in San Francisco. Despite the late afternoon meeting time and the small size of the room, about 60 persons attended. Tony Judt of Berkeley, John Laslett of UCLA, and Ron Schatz of Stanford gave brief presentations on recent trends and developments in labor history. Judt focused on the European scene, discussing in particular the shift from traditional accounts of particular occupational groups, labor organizations, or major strikes to a broader social history of the working class in Europe. Schatz and Laslett examined similar themes in their discussions of recent writings in American labor history. A brief period for comments and questions followed before the convening of the business meeting.

Those attending the business meeting expressed the importance of keeping the Study Group alive and toward this end agreed to set up a Continuations Committee to consider questions of structure and activities and to report back to the 1979 business meeting in New York with specific recommendations. Volunteers to serve on the committee were sought, with a view that a variety of areas of study and geographical regions of residence be included. The following individuals have agreed to serve:

Frank Arnold, Southwest Labor Studies Conference, San Jose, Cal.

Ed Beechert, History Dept., University of Hawaii

Victoria DeGrazia, New York City

Jonathan Grossman, Department of Labor, Washington, D.C.

Bernard Moss, Los Ángeles, Cal.

Dale Newman, History Dept., University of Pittsburgh

Masao Nishikawa, University of Tokyo

Ron Schatz, Dept. of History, Stanford University

Louise Tilly, Dept. of History, University of Michigan

There was a general consensus at the meeting that those attending would like to see the Study Group co-sponsor a concurrent session at next year's annual meeting of the AHA and hold a regular business meeting as well. Members of the Continuations Committee will discuss proposals that may be brought to the business meeting. The meeting place and time will be announced in the next issue of $I L W C H$ and possible agenda items indicated. Members should be aware that this will be a substantive business meeting, and it would be helpful if those at the AHA meeting would make every effort to attend. In the meantime, anyone with suggestions concerning the Study Group is asked to contact members of the Continuations Committee.

\section{Tom Dublin}

University of Califormia, San Diego 